\title{
Resisting general models
}

\author{
Peter VAN DER VeER, Max Planck Institute for the \\ Study of Religious and Ethnic Diversity, Göttingen
}

Response to comments on van der Veer, Peter. 2016. The value of comparison. Durham, NC: Duke University Press.

It would be surprising if my fellow anthropologists would not welcome a book that extolls the value of the anthropological contribution to comparative research in the social sciences. I am grateful for their responses, but I do hope that other social scientists, especially sociologists and political scientists, will also read the book and engage with it. Alternatively, the book may be useful in conversations with other social scientists. Birgit Meyer and I share a long-term experience with governing bodies of universities and funding agencies in which one is often confronted with an astounding lack of recognition for the ideographic tradition of anthropology, especially in the face of the rise of cognitive science and big data. We have often found ourselves defending anthropology against accusations that it not scientific and especially has no generalizable results. Birgit Meyer points at the use of comparison as critique, especially of ethnocentric assumptions about "how people think universally." Anthropological comparison goes beyond critique by contributing positively to our understanding of important but neglected fragments of social reality. As Matei Candea rightly observes, my book shows by example and not by grand abstraction how valuable anthropological understandings of seemingly insignificant elements of social reality are for the interpretation of big questions surrounding the notion of civilization, the problems of social inequality, and the pitfalls of nationalism. It is also very gratifying that he understands my resistance toward making a general model of comparison, since that indeed would defeat my purpose. Anthropologists do make very significant contributions to social science understandings of the world we live in, but do so precisely because of the specificity and particularity of their knowledge and interpretative skill. In 
that way, anthropological knowledge goes far beyond the generalisms offered in other parts of the social science domain. The assumptions of rational choice and well-understood self-interest in much social science research on markets (that also include religious markets), urban planning, social welfare, or political alliance allow for generalizations that seriously fail to contribute to social analysis.

I do not see this book as presenting a "weak form of sociology", as Annelin Eriksen suggests, but as a strong form of social anthropology that refuses to foreground a unifying concept of "culture." Indeed, I address some major issues in the study of India and China without assuming a civilizational "whole," such as the "individualistic West" or "the hierarchical East." I have always admired Louis Dumont's thorough knowledge of the ethnography of India and it is precisely through ethnography that his homogenizing culturalist assumptions in Homo Hierarchicus (1980) were challenged by a younger generation of anthropologists, including myself. When one works on huge societies such as India and China, that show a wide variation in historical traditions and that have been transformed into nationstates, it is especially not advisable to start with the assumption of an integrated model of culture. The Dumontian opposition of Homo Hierarchicus (India) and Homo Equalis (Europe) is indeed a general analytical model and in its positing of an Indian "whole" versus a Western "whole," it creates artificial unities over time and space, which is fundamentally misleading. The problems it creates for understanding modern India have been recognized early on by the Indian anthropologist Andre Beteille (1986), but even in the religious sphere to see the renouncer as the individual outside of the social world is not helpful for the ethnographic understanding of really existing ascetic movements in India (van der Veer 1988). It is inevitable that there are many different readings of Dumont's work and the one by de Coppet and his followers in work on Oceania is almost unrecognizable for Indianists, which ironically shows the fragmentation of our discipline. However, I cannot understand why Eriksen thinks that a critique of Dumontian essentialism has anything to do with representativity and quantification. Very simply, the model made by Dumont obscures Indian society to the extent that it becomes unrecognizable, and that does not have to be quantified. That is not to say that there are no parts of Dumont's work that can be put to good analytical use, as indeed is the case in the comparison between race and caste, but again one cannot use Dumont's arguments here as a whole but only partly. Dumont's assumption that India's hierarchical ideology is a shared all-encompassing system of values is unacceptable. The difference between Eriksen and me is ultimately that I reject general models of unified culture and doubt their analytical purchase. In fact, in my discussion of India, China, and Europe (a large part of humanity) I show that civilizational models resemble in one way or the other the self-representation of the nation-state.

This is precisely my critique of Francis Hsu's work on China and India that it is both culturalist and nationalist. Stephan Feuchtwang thinks that I endorse Francis Hsu's theories, because Hsu is a native speaker. This is plainly the opposite of what I write. It is Hsu's opinion that a native anthropologist is superior, not mine. In fact, what I try to show is how much Hsu was suffering from what he considered to be a lack of recognition of himself as a Chinese anthropologist, especially by his British colleagues. Concerning the controversy between Leach and Hsu about the nature of the Bai ethnicity both C. P. Fitzgerald (1941, mentioned by Feuchtwang) 
and Yongjia Liang (2011, whom Feuchtwang seems not to have read) come to the conclusion that there is very little difference between the Minjia (Bai) and the Han except for language. In fact, according to Liang the Bai referred to themselves as Han in the period that Hsu was doing his fieldwork. A similar misreading by Feuchtwang of what I write is that I express doubt on Edmund Leach's command of the Kachin language. How could I possibly have an opinion on that? What I do point out in the book is that recent research in the area by Mandy Sadan, Francois Robinne, and others (2007) puts considerable doubt on Leach's understanding of gumsa and gumlao. When one compares, and certainly on the large canvas that I use to show examples of comparison, one needs to rely on current anthropological knowledge of things and places that one does not know first-hand.

Birgit Meyer raises a number of important questions about comparison. The problem of translation of other languages and conceptual traditions into English is certainly important and has occupied scholars constantly, but reflection on these difficulties and on the power relations that inhabit the differences between languages certainly helps to refine anthropological analysis. That critical reflection often shows that Western concepts do not fit the social reality one wants to investigate and, unfortunately, may lead to the exaggerated claim that societies outside the West should be understood in their own terms and cannot be understood in Western terms. However, one cannot escape the fact that in today's world "native" terms have to be interpreted and translated in relation to "Western" scholarship. Moreover, such translation and interpretation is part of a long history of interactions with the West that became dominant in the nineteenth century. Any attempt to make a sharp (often nationalistic) demarcation of inside and outside is spurious in contemporary society. Meyer rightly points out (as I do on page 32 of The value of comparison [2016]) that our interlocutors also are constantly engaged in comparison (past and present; us and others). This is part of the social reality that we try to understand. Part of our job is to compare ways of comparing, as in Aristide Zolberg and Long Litt Woon's brilliant 1999 article on incorporation of minorities in Europe and the United States, "Why Islam is like Spanish." It is clear that one cannot do the work of comparison on one's own and that one needs an intensification of collaboration across borders that does not fetishize regional expertise. One needs to compare pragmatically so that comparison sheds light on what one wishes to understand. Sometimes something that seems so radically different that it appears to escape comparison is something that really leads us to a new discovery of what we thought was familiar.

\section{References}

Beteille, Andre. 1986. "Individualism and equality." Current Anthropology 27 (2): 121-34.

Dumont, Louis. 1980. Homo Hierarchicus: The caste system and its implications. Chicago: University of Chicago Press.

Fitzgerald, C. P. 1941. The tower of five glories: A study of the Min Chia of Dali, Yunnan. London: Cresset. 
Liang, Yongjia. 2011. "The 'ethnic error' in Under the Ancestor's Shadow and Dali Society in the Period of the Nationalist Government." Chinese Sociology and Anthropology 42 (4): $78-94$.

Sadan, Mandy, and Francois Robinne, eds. 2007. Social dynamics in the Highlands of South East Asia: Reconsidering Political Systems of Highland Burma by E. R. Leach. Handbook of Oriental Studies, sec. 3, Southeast Asia. Leiden: Brill.

van der Veer, Peter. 1988. Gods on Earth: the management of religious experience and identity in a North Indian Pilgrimage Centre. LSE Monographs in Social Anthropology. London: Athlone.

- 2016. The value of comparison. Durham, NC: Duke University Press.

Zolberg, Aristide, and Long Litt Woon. 1999. "Why Islam is like Spanish: Cultural incorporation in Europe and the United States." Politics \& Society 27 (1): 5-38.

Peter van der Veer Max Planck Institute for the Study of Religious and Ethnic Diversity Hermann Fögeweg 11 D-37073 Göttingen Germany vanderveer@mmg.mpg.de 